\title{
Ceritinib-Induced Regression of an Insulin-Like Growth Factor-Driven Neuroepithelial Brain Tumor
}

\author{
Alexandra Russo ${ }^{1,2,+}$, Claudia Paret ${ }^{1,2,3,+, * \mathbb{D}}$, Francesca Alt ${ }^{1,2}$, Jürgen Burhenne ${ }^{4}$, \\ Margaux Fresnais 4,5 (D), Wolfgang Wagner 2,6 , Martin Glaser 2,6 , Hannah Bender 1,2, \\ Sabrina Huprich 1,2 , Patrick N. Harter ${ }^{3,7,8}$, Katharina Filipski ${ }^{3,7}$, Nadine Lehmann 1,2(D), \\ Nora Backes ${ }^{1,2}$, Lea Roth ${ }^{1,2}$, Larissa Seidmann ${ }^{9}$, Clemens Sommer ${ }^{2,10}$, Marc A. Brockmann 2,11, \\ Torsten Pietsch ${ }^{12}$, Marie A. Neu 1,2, Arthur Wingerter ${ }^{1,2}$ and Jörg Faber 1,2,3 (D) \\ 1 Pediatric Hematology/Oncology, Children's Hospital, University Medical Center of the Johannes \\ Gutenberg-University Mainz, 55131 Mainz, Germany \\ 2 University Cancer Center of the University Medical Center of the Johannes Gutenberg-University, \\ 55131 Mainz, Germany \\ 3 German Cancer Consortium (DKTK), site Frankfurt/Mainz, Germany, German Cancer Research \\ Center (DKFZ), 69120 Heidelberg, Germany \\ 4 Department of Clinical Pharmacology and Pharmacoepidemiology, Heidelberg University, \\ 69120 Heidelberg, Germany \\ 5 German Cancer Consortium (DKTK)-German Cancer Research Center (DKFZ), 69120 Heidelberg, Germany \\ 6 Section of Pediatric Neurosurgery, Department of Neurosurgery, University Medical Center of the Johannes \\ Gutenberg University Mainz, 55131 Mainz, Germany \\ 7 Neurological Institute (Edinger-Institute), Goethe-University Medical School, \\ 60528 Frankfurt am Main, Germany \\ 8 Frankfurt Cancer Institute (FCI), 60596 Frankfurt am Main, Germany \\ 9 Institute of Pathology, University Medical Center of the Johannes Gutenberg University Mainz, \\ 55131 Mainz, Germany \\ 10 Institute of Neuropathology, University Medical Center of the Johannes Gutenberg University Mainz, \\ 55131 Mainz, Germany \\ 11 Department of Neuroradiology, University Medical Center of the Johannes Gutenberg University, \\ 55131 Mainz, Germany \\ 12 Department of Neuropathology, DGNN Brain Tumor Reference Center, University of Bonn, \\ 53127 Bonn, Germany \\ * Correspondence: claudia.paret@unimedizin-mainz.de; Tel.: +49-6131-17-4370 \\ + These authors contributed equally to this work.
}

Received: 5 July 2019; Accepted: 28 August 2019; Published: 30 August 2019 updates

\begin{abstract}
The insulin-like growth factor (IGF) pathway plays an important role in several brain tumor entities. However, the lack of inhibitors crossing the blood-brain barrier remains a significant obstacle for clinical translation. Here, we targeted the IGF pathway using ceritinib, an off-target inhibitor of the IGF1 receptor (IGF1R) and insulin receptor (INSR), in a pediatric patient with an unclassified brain tumor and a notch receptor 1 (NOTCH1) germline mutation. Pathway analysis of the tumor revealed activation of the sonic hedgehog (SHH), the wingless and integrated-1 (WNT), the IGF, and the Notch pathway. The proliferation of the patient tumor cells (225ZL) was inhibited by arsenic trioxide (ATO), which is an inhibitor of the SHH pathway, by linsitinib, which is an inhibitor of IGF1R and INSR, and by ceritinib. 225ZL expressed INSR but not IGF1R at the protein level, and ceritinib blocked the phosphorylation of INSR. Our first personalized treatment included ATO, but because of side effects, we switched to ceritinib. After 46 days, we achieved a concentration of $1.70 \mu \mathrm{M}$ of ceritinib in the plasma, and after 58 days, MRI confirmed that there was a response to the treatment. Ceritinib accumulated in the tumor at a concentration of $2.72 \mu \mathrm{M}$. Our data suggest ceritinib as a promising drug for the treatment of IGF-driven brain tumors.
\end{abstract}




\section{Introduction}

Brain tumors are the most common solid tumors and a leading cause of cancer-related death in children. The advances in molecular biology have identified critical cellular changes within pediatric brain tumors, suggesting that molecularly targeted therapy may improve the treatment of these patients.

The insulin-like growth factor (IGF) pathway has long been recognized for its role in tumorigenesis and growth. The IGF axis includes three ligands (IGF1, IGF2, and insulin) and two homolog receptors, insulin like growth factor 1 receptor (IGF1R) and insulin receptor (INSR; for a review, see [1]). In the brain, IGF1R, IGF1, and IGF2 are highly expressed during embryonic and early postnatal development, and decrease substantially during adolescence [2]. In brain tumors, the IGF axis is frequently activated in medulloblastoma [3,4] glioblastoma [5], and ependymoma [6]. Several strategies have been tested to interfere with IGF signaling, including IGF1R blockade by monoclonal antibodies, small molecule tyrosine kinase inhibitors of IGF1R and INSR, and ligand neutralizing strategies [7], but so far, there are no US Food and Drug Administration (FDA)-approved drugs available. Thus, drug repositioning i.e., the strategy of using existing drugs originally developed for one disease to treat other indications, may represent a way forward to rapid clinical use.

Ceritinib gained US Food and Drug Administration approval in 2014 for the treatment of patients with ALK-positive metastatic non-small-cell lung cancer (NSCLC) who have progressed on or are intolerant to crizotinib [8]. Ceritinib can also inhibit INSR and IGF1R [9], suggesting a potential role in the development of therapy protocols targeting the IGF axis. Ceritinib indeed has been used to successfully inhibit IGF1R phosphorylation in models of rhabdomyosarcoma [10] and of high-grade neuroepithelial tumor with BCOR alteration (HGNET-BCOR) [11].

Here, we targeted the IGF pathway in a pediatric patient with a neuroepithelial tumor that was neuropathologically classified as an anaplastic ependymoma, but could not be assigned to a defined DNA-methylation class of brain tumors. Our in vitro and in vivo data indicate that ceritinib can be used to target INSR, and that ceritinib penetrates the human blood-brain barrier (BBB).

\section{Results}

\subsection{Clinical Description}

A 4-year-old female patient without any relevant prior medical condition was transferred to our center after the gross total microsurgical resection of a $5.1 \times 3.6 \times 2.1 \mathrm{~cm}$ hemorrhagic tumor in the right parieto-occipital lobe. The postoperative staging scans revealed no metastases. The tumor was classified as an anaplastic ependymoma (WHO III), and the patient received focal irradiation according to the international HIT-MED registry (Version 1.0, 12 January 2014). Five months after cessation of radiotherapy, a first metastatic relapse occurred in the temporofrontal region. Gross total microsurgical resection of the first metastasis was performed, and we initiated systemic chemotherapy based on cycles of cyclophosphamide/vincristine and carboplatin/etoposide according to the HIT-MED Guidance (Ependymoma, M0, R0, 4-21 years and protocol version 3.0, 16th September 2015). Four months later, the patient developed a second metastasis/metachronous tumor in the temporomesial region, and we decided to switch to a personalized treatment based on the molecular analysis of the tumor.

\subsection{Histopathology}

The histopathological report of the primary tumor was suggestive of a small, round, blue cell tumor with co-expression of neuronal antigens (NeuN and CD56) and epithelial antigens (EMA) (Figure 1B-D). Ki67 staining was indicative of more than $10 \%$ proliferating tumor cells (Figure 1E). Further central reference pathological review and additional molecular evaluation (RT-PCR and sequencing) led to the 
diagnosis of an anaplastic ependymoma (WHO III) carrying a C11orf95-RELA fusion. However, L1Cam, a surrogate marker for RELA fusion-gene positivity, was detected only in a subfraction of tumor cells (Figure 1F). Moreover, in this specimen, subpopulations of cells showed nuclear accumulation of the p65RelA protein as specific indication of NFKB activation [12] (not shown). The tumor protein P53 (TP53) gene product was accumulated in approximately $20 \%$ of cells. Histology of the first metastatic relapse revealed a tumor lacking any characteristic patterns (Figure S1). The tumor cells were round to oval and of varying size, with only a scant cytoplasm. Sometimes, distinct nucleoli were present. Mitotic activity was brisk. There was geographic necrosis. Immunohistochemically, most tumor cells were positive for EMA, while some displayed positivity for L1Cam. P53 accumulation was present in the majority of cells Nuclear INI1-positivity was retained (Figure S1). The tumor was negative for glial fibrillary acidic protein (GFAP) and isocitrate dehydrogenase (NADP(+)) 1 (IDH1) R132H (Figure S1). The Ki67 proliferation index was up to about 50\%. Interestingly, the C11orf95-RELA fusion could not be detected, and the tumor cells did not show nuclear accumulation of p65RelA protein.
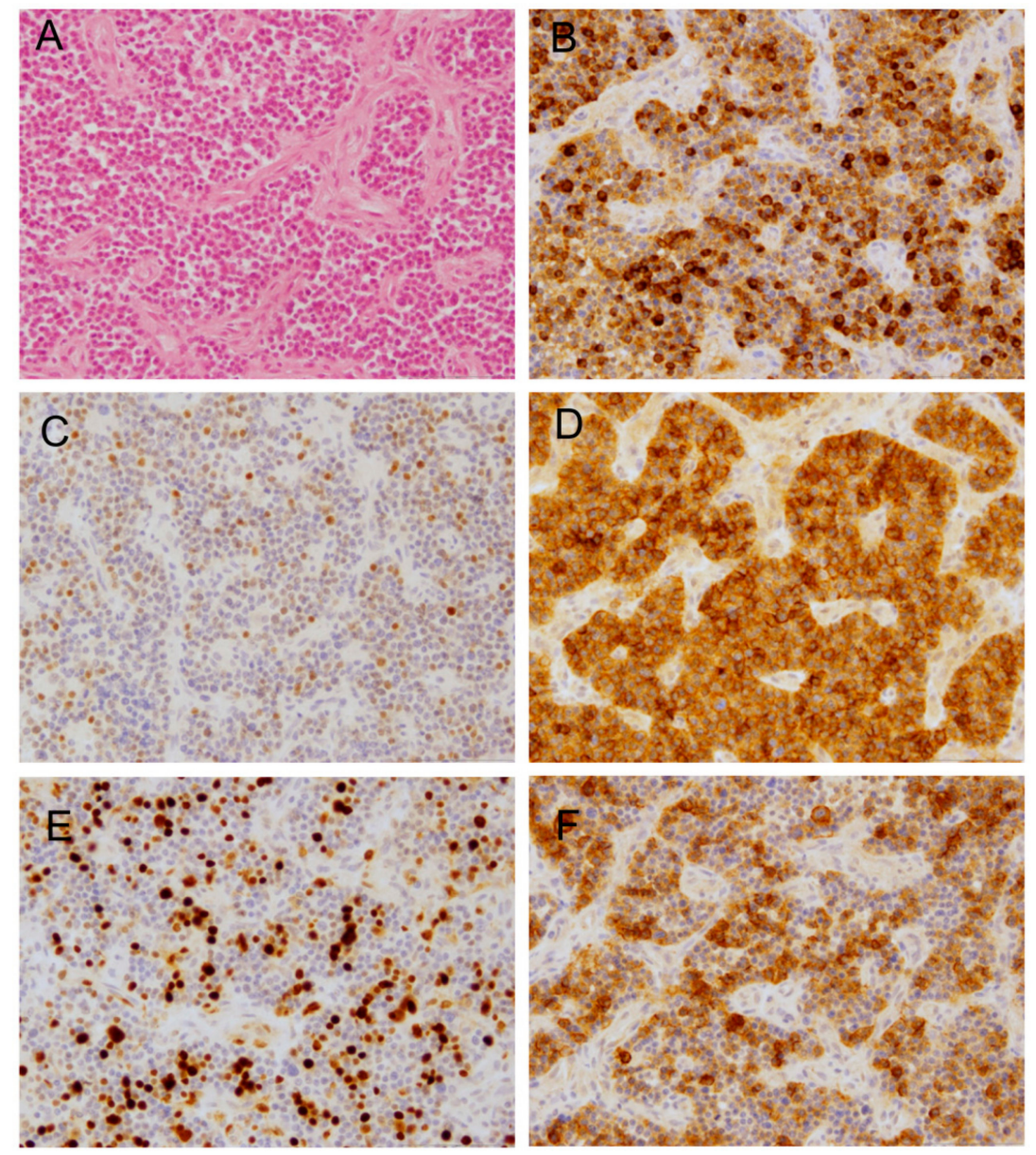

Figure 1. Histopathological features of the primary tumor. (A) HE staining showing small, round, blue tumor cells. (B) Epithelial antigens (EMA). (C) NeuN. (D) CD56. (E) Ki67. (F) L1Cam. Original magnification $200 \times$.

\subsection{Methylation Analysis Reveals a not Classifiable Tumor Entity}

Due to the unexpected loss of the C11orf95-RELA fusion gene, we analyzed the primary tumor and the first metastatic relapse by 850k DNA methylation bead array analysis and the brain tumor classification tool recently described by Capper et al. (classifier version v11b4) [13]. The DNA methylation signatures of the primary tumor (no. 176), the metastasis (no. 225), and of the primary tumor cells isolated from the metastasis and grown in vitro (no. $225 \mathrm{ZL}$ ) did not show similarities with 
any known brain tumor DNA methylation class defined in this classifier version (Table 1), and thus were not classifiable by this method. A principal component analysis of genes conducted with the $\mathrm{R}$ package "RnBeads" indicated that the three samples cluster together, but not with C11orf95-RELA fusion gene positive ependymoma samples (Figure 2). These results argue for intermethodological discrepancies in the primary tumor, as RT-PCR and sequencing detected a C11orf95-RELA fusion gene, although 850k DNA methylation analysis did not show an association with the DNA methylation class of the C11orf95-RELA fusion gene positive ependymoma.

Table 1. Results of the methylation classifier and summary of the chromosomal aberrations.

\begin{tabular}{cccc}
\hline Sample Type & Sample ID & $\begin{array}{c}\text { Methylation } \\
\text { Classifier'Result }\end{array}$ & Chromosomal Aberrations \\
\hline Primary tumor & 176 & unclassified & Gain on chromosome 2 and 11q \\
\hline $\begin{array}{c}\text { First metastatic relapse } \\
\text { in vitro culture of } \\
\text { tumor cells }\end{array}$ & 225 & unclassified & $\begin{array}{c}\text { Tendency to gain on chromosomes 1p, 2, } \\
\text { 7q partially, 11q, 21q; } \\
\text { loss of chromosomes 17p, 19p }\end{array}$ \\
\hline $\begin{array}{c}\text { unclassified } \\
\text { 225 ZL }\end{array}$ & $\begin{array}{c}\text { Gain on chromosomes 1p, 2, 7q partially, } \\
11 \mathrm{q}, \text { 21q; }\end{array}$ \\
loss of chromosomes 17p, 18q, 19p
\end{tabular}

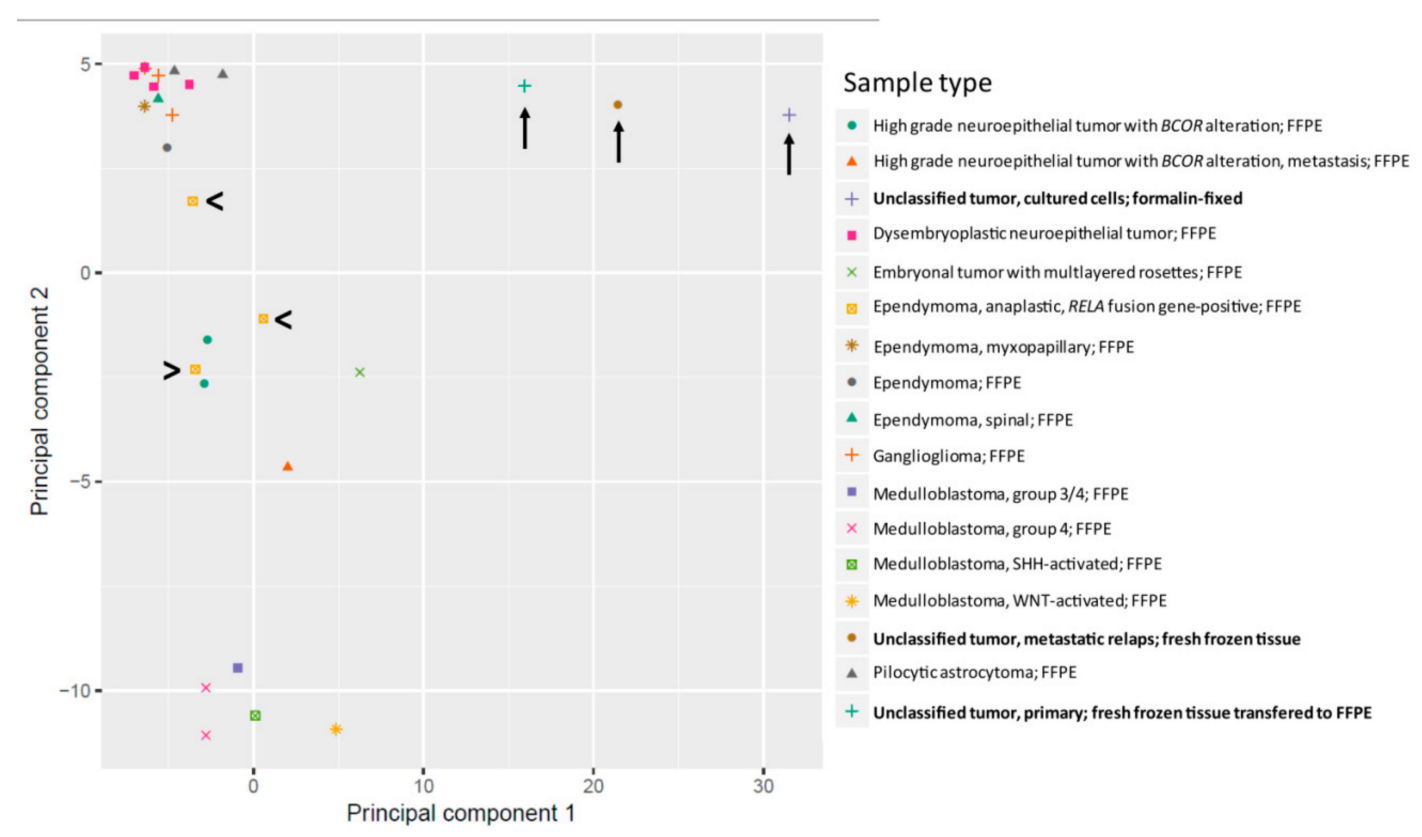

Figure 2. Principal Component Analysis. Principal component analysis by genes based on $850 \mathrm{k}$ DNA methylation analysis for different tumor entities commonly found in childhood. Samples of the index patient do not cluster together with ependymoma, RELA fusion-positive tumors (arrow heads), but rather form their own cluster (arrows). The kind of material used for the analysis is indicated (fresh frozen or formalin-fixed, paraffin-embedded (FFPE)).

The copy number profile derived from the DNA methylation array data revealed a gain of chromosome 2 and chromosome 11q in the primary tumor (Table 1 and Figure S2). The first metastatic relapse further showed gains of chromosomes $1 p$, partially of $7 q$ and $21 q$, and losses of chromosomes $17 \mathrm{p}$ and $19 \mathrm{p}$. The copy number profiles of primary tumor cells showed an additional loss of chromosome 18q. 


\subsection{Whole-Transcriptome Sequencing Reveals the Activation of Several Embryonic Pathways}

To identify therapeutic targets, whole-transcriptome sequencing (RNAseq) was performed using fresh frozen tissue from the first metastatic relapse (no. 225) and normal tissue derived from normal parietal brain (no. 111). To identify only strongly deregulated pathways, we first calculated the ratio of the expression between the tumor tissues and the normal tissue, and selected the genes with a fold change $>10$. This data set was functionally analyzed using the 'core analysis' of IPA. The activated pathways are shown in Table 2. The Notch and basal cell carcinoma (BCC) pathways had the lowest $p$ value ( $p=0.00024$ and $p=0.0028$, respectively). The BCC pathway is characterized by a cross-talk between the sonic hedgehog $(\mathrm{SHH})$ and the wingless and integrated-1 (WNT) signaling [14]. Deregulated genes of the Notch and BBC pathways are listed in Table S1 and Table S2, respectively. Other pathways activated in the relapse included the G12 subfamily (G $\alpha 12 / 13)$-mediated signaling pathway [15] $>(p=0.0074)$. Since the first diagnosis of the tumor was of an ependymoma and IGF has been recently identified as relevant target in this entity [16], we also searched the transcriptome data for the expression of components of the IGF pathway. We observed a very strong expression of IGF2, but not of IGF1 (Table S3). In line with the results of the reference pathology, we were not able to detect a C11orf95-RELA fusion in the RNAseq data. However, we detected other fusions (Table 3), involving nuclear receptor coactivator 1 (NCOA1) and GRB interacting GYF Protein 2 (GIGYF2) (both on chr.2) and NCOA1 (chr.2) and C11orf95 (chr.11). Fusions between C11orf95 and NCOA1, a steroid receptor, have been described in a C11orf95-RELA negative supratentorial anaplastic ependymoma [17], but their biological significance is unknown so far. Two fusions contained intronic sequences, and are probably not functionally relevant. One fusion contained exon 8 of GIGYF2, which is a gene that is involved in the regulation of the IGF signaling [18]. Whether the disruption of the GIGYF2 locus has an effect on the activation of the IGF signaling in this patient remains to be elucidated.

Table 2. Pathways activated in the first metastatic relapse. The -log of $p$-value (calculated by Fisher's exact test right-tailed) is indicated. Only pathways with a -log of $p$-value of more than 2 are shown.

\begin{tabular}{cc}
\hline Ingenuity Canonical Pathways & -Log $(\boldsymbol{p}$-value) \\
\hline Notch Signaling & 3.62 \\
\hline Basal Cell Carcinoma Signaling & 2.55 \\
\hline G $\alpha 12 / 13$ Signaling & 2.13 \\
\hline
\end{tabular}

Table 3. Fusion transcripts detected by RNA Seq.

\begin{tabular}{cccccc}
\hline Transcript 1 & Chr & Position & Transcript 2 & Chr & Position \\
\hline NCOA1 intron7 & 2 & $24914529-24916118$ & GIGYF2 exon8 & 2 & 233626104-233626145 \\
\hline NCOA1 intron12 & 2 & $24933980-24949455$ & GIGYF2 intron8 & 2 & $233626146-233651857$ \\
\hline NCOA1 intron12 & 2 & $24933980-24949455$ & C11orf95 intron3 & 11 & $63532726-63533276$ \\
\hline
\end{tabular}

We further validated the RNAseq results by qRT-PCR using GLI family zinc finger 2 (GLI2), AXIN2, and hes family bHLH transcription factor 4 (HES4) as surrogate markers for the activation of the SHH, WNT, and Notch pathways, respectively. A strong upregulation of GLI2, AXIN2, and HES4 was detected in the relapse compared to the two normal brain regions (Figure $3 \mathrm{~A}-\mathrm{C}$ ). High expression of IGF2 was also detectable in the relapse material by qRT-PCR (Figure 3D). In conclusion, the transcriptome analysis indicated a co-activation of several pathways known to play an important role in the tumor progression and embryogenesis. 
A

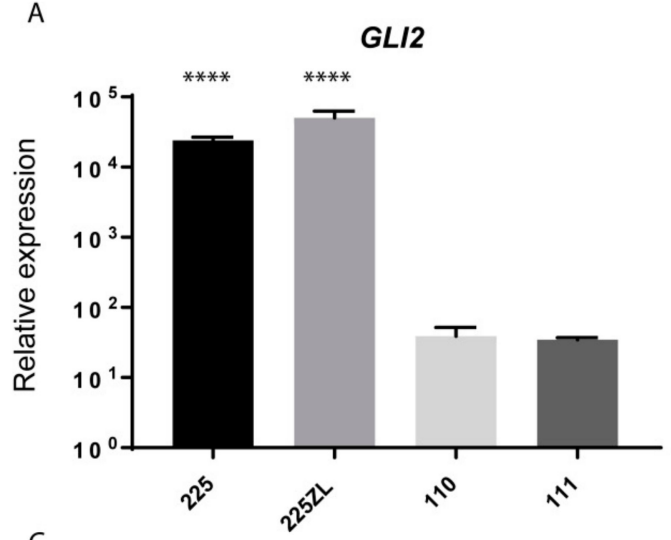

C

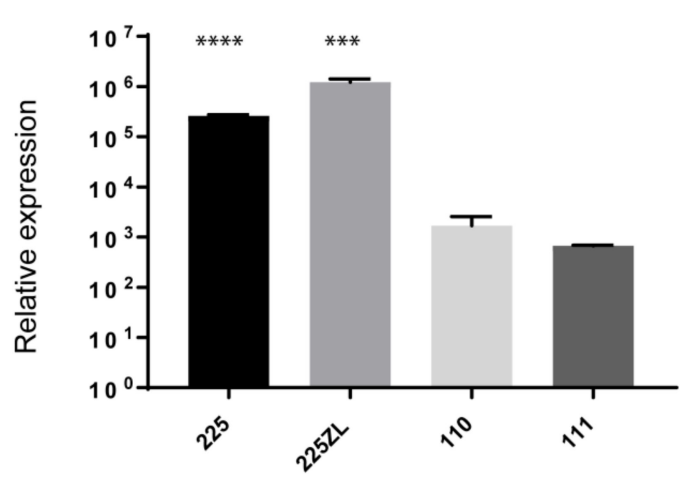

B

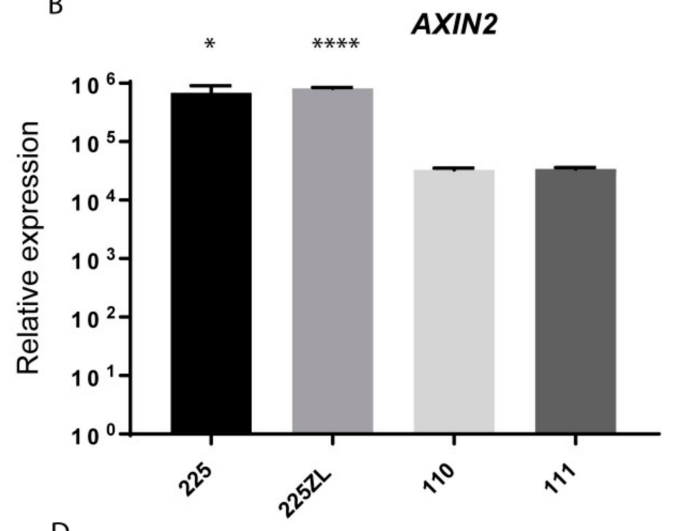

D

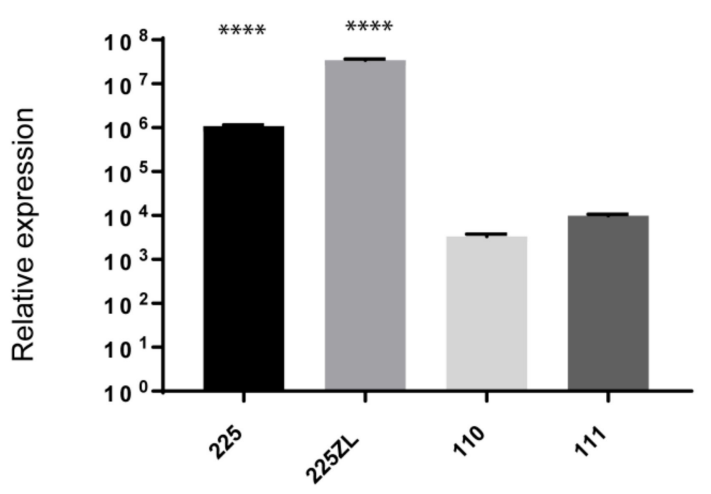

Figure 3. Embryonal pathways are activated in the tumor relapse. GLI family zinc finger 2 (GLI2) (A), AXIN2 (B), hes family bHLH transcription factor 4 (HES4) (C) and insulin-like growth factor 2 (IGF2) (D) expression was analyzed by qRT-PCR in the relapse (no 225), the primary tumor cells isolated from the relapse (no 225ZL), and two normal brain regions (no 110,111). After normalization to the housekeeping gene hypoxanthine phosphoribosyltransferase 1 (HPRT1), the relative quantification value was expressed as $2^{-\Delta \Delta C t}$. The qPCR experiments were carried out in biological triplicates. Data are represented as the mean \pm standard deviation (SD). Statistical analyses were performed using $t$-tests compared with sample $111\left({ }^{*} p<0.01,{ }^{* * *} p<0.001,{ }^{* * * *} p<0.0001\right)$.

\subsection{Detection of a NOTCH 1 Germline Mutation}

Due to the activation of the Notch signaling pathway, we searched for mutations in related genes in the RNAseq data, and detected a mutation in exon 3 of notch receptor 1 (NOTCH1) (NM_017617.3:c.689G $>$ A). Validation by Sanger sequencing indicated that the mutation was present not only in the tumor, but also in the lymphocytes of the patient (Figure 4A). The mutation is localized at the $\mathrm{N}$ terminus of NOTCH1 (NP_060087.3:p.Gly230Glu) in the fourth EGF-like domain according to cBioPortal [19] (Figure 4B), and is predicted to be damaging, according to polyphene [20]. A somatic mutation at this position has been described previously in a basal cell carcinoma patient [21]. In the DNA of the tumor, but not of the blood, a TP53 homozygous mutation was also detected (NM_000546.5:c.742C > T, rs121912651) (Figure 4C). This mutation is localized in the DNA binding domain (NP_000537.3:p.Arg248Trp), and is predicted to be pathogenic according to ClinVar [22]. No mutations in $A L K$ were detected by Sanger sequencing with primers covering the kinase domain [23]. 
A
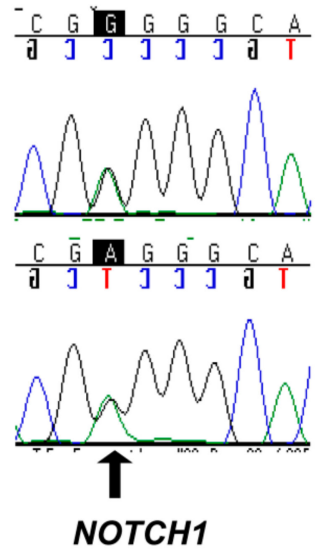

B

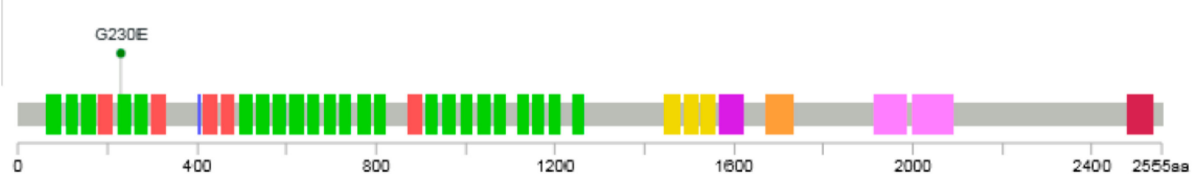

C

Blood
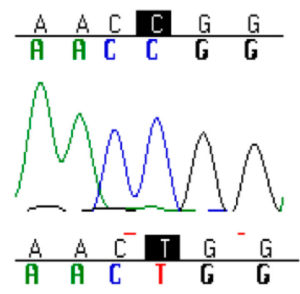

Relapse

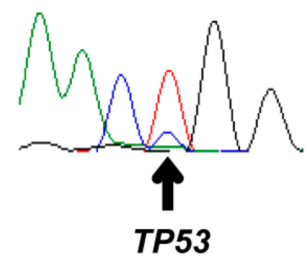

Blood

Relapse

Figure 4. Detection of a notch receptor 1 (NOTCH1) germline mutation and a tumor protein P53 (TP53) somatic mutation. Sanger sequencing of the genomic DNA extracted from the blood and the relapse (no 225) was done with primers specific for the NOTCH1 (A) and the TP53 (C) mutation identified by RNA-seq. The arrow indicates the (NM_017617.3:c.689G > A) mutation rs121912651. The arrowhead indicates the rs121912651. (B) Structure of NOTCH1 as reported in cBioportal. The position of the Gly230Glu mutation is indicated. Green: EGF-like domains; Red: Calcium-binding EGF domains; Yellow: LNR Domain; Purple: NOD (NOTCH protein domain); Orange: NODP (NOTCH protein domain); Rose: Ankyrin repeats; Dark red: unknown function.

\subsection{The Primary Tumor Cells are Sensitive to Inhibition with ATO and Ceritinib}

The transcriptome analysis revealed the $\mathrm{SHH}, \mathrm{WNT}$, Notch, and IGF pathways as putative targets for a personalized therapy protocol. We selected the pathways to treat based on the biological relevance of the pathways, safety concerns, and the availability of FDA-released drugs. To date, there is no approved Notch and WNT targeted therapy in the clinic, and the development of life-threatening toxicities associated with the targeting of these pathways still remain a concern [24,25]. The SHH pathway can be targeted using vismodegib, which is an inhibitor of smoothened (SMO) that has been approved for the treatment of the BCC [26], and ATO, an inhibitor of GLI2 [27,28]. The administration of ATO is well established in the treatment schedule of pediatric acute promyelocytic leukemia (APL) [29]. No inhibitors for IGF1R have been released so far, but it is known from clinical studies that the inhibition of the IGF pathway has an acceptable safety profile [30]. Moreover, ceritinib, which is approved for anaplastic lymphoma kinase (ALK) positive lung cancer, can also inhibit IGF1R and INSR [9]. We previously showed that ceritinib can inhibit the IGF receptor IGF1R in a particular subtype of pediatric brain tumors at a concentration that is achievable in vivo [11]. To evaluate if the targeting of the SHH and the IGF1R pathway could affect the growth of the tumor and to prioritize related drugs, we tested the effect of relevant drugs on the tumor cells (225ZL) isolated from the first relapse of the patient. We first analyzed to what extent the 225ZL cells constituted the tumor of origin. By DNA methylation analysis, the primary tumor cells were not assigned to any known brain tumor DNA methylation profile, but clustered together with the tumor of origin (Table 1 and Figure 2). Chromosomal aberrations were similar to the first metastasis with an additive loss of chromosome $18 \mathrm{q}$ (Table 1 and Figure S2). The Notch, SHH, and WNT pathways were active, as shown by qRT-PCR analysis of the target genes (Figure 3A-C). IGF2 was highly expressed (Figure 3D). Then, we treated 
the 225ZL cells with ATO, vismodegib, and linsitinib, a specific but not FDA-approved inhibitor of IGF1R and INSR [31], and ceritinib. While vismodegib at a concentration of $10 \mu \mathrm{M}$ reduced the cell proliferation to about $85 \%$ of the control, ATO, linsitinib, and ceritinib (all at the concentration of 1 $\mu \mathrm{M}$ ) reduced the cell proliferation to about $16 \%, 20 \%$, and $30 \%$ of the control respectively, after 15 days (Figure $5 \mathrm{~A}$ ). Notably, we selected the $1-\mu \mathrm{M}$ concentration of ceritinib and linsitinib, because this concentration can be achieved in the plasma of patients [8,32], and is therefore clinically relevant. To identify the molecular target of ceritinib, we analyzed the expression of IGF1R and INSR by Western blot (Figure 5B). Only INSR was expressed by the 225ZL cells. Stimulation with IGF2 induced INSR phosphorylation in starved cells (Figure 5B, lane 2). The phosphorylation could be blocked using ceritinib (Figure 5B, lane 3). These data indicate that GLI2 and INSR are relevant targets to be addressed in a personalized therapy protocol, and that ceritinib can be used to target the IGF pathway.

A

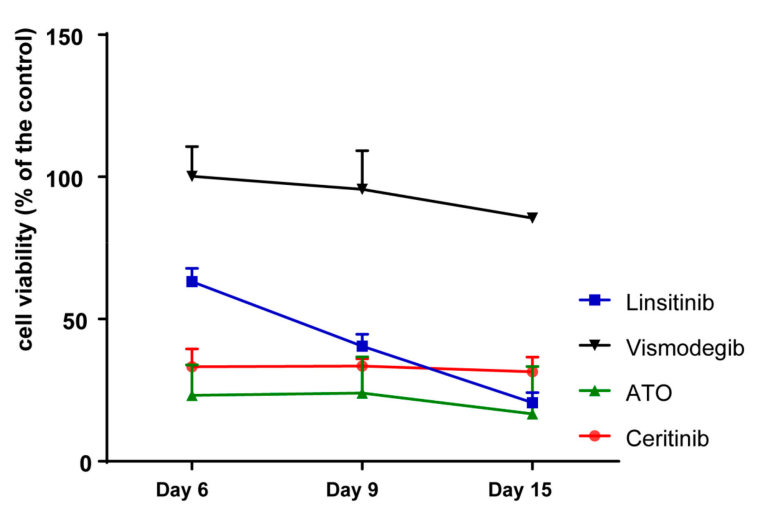

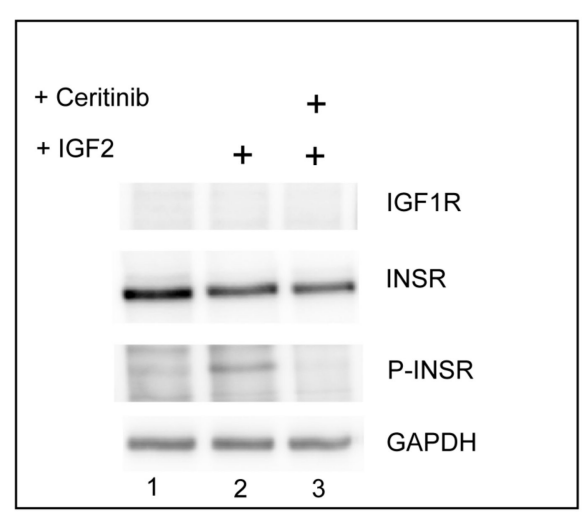

Figure 5. The primary tumor cells are sensitive to arsenic trioxide (ATO) and ceritinib. (A) 225ZL cells were grown for 15 days in the presence of ATO, vismodegib, linsitinib, or ceritinib. As control, the vehicle alone was used. The percentage of the growth compared to the control is shown. The proliferation experiments were carried out in biological duplicates. Data are represented as the mean \pm standard deviation (SD). (B) 225ZL cells were stimulated after starvation with IGF2 in the presence or absence of $1 \mu \mathrm{M}$ of ceritinib. The expression of IGF1R, insulin receptor (INSR), and the phosphorylated form of INSR (P-INSR) was analyzed by Western blot with specific antibodies. Glyceraldehyde-3-phosphate dehydrogenase (GAPDH) was used as loading control. A representative experiment of two independent experiments is shown.

\subsection{Ceritinib Induces Tumor Regression in Vivo}

Following the second relapse and in the absence of established treatment options, we switched to a personalized therapy protocol based on our molecular analysis of the tumor and our in vitro model (Figure 6). We decided to start with the inhibition of the SHH pathway, because the involvement of the SHH pathway in the biology of pediatric brain tumors is well established [33]. We did not use vismodegib to target the SHH pathway, because in our in vitro model, vismodegib reduced the cell proliferation to about $85 \%$ of the control, while the effect on the proliferation of ATO was much more impressive (about $16 \%$ of the control). Moreover, SMO inhibition causes permanent defects in bone structure in young mice and young children, and its use has to be carefully considered with respect to long-term toxicities [34,35]. As a chemotherapy backbone, we incorporated systemic VA (vincristine and actinomycin-D) and VAd (adriamycin) cycles and intraventricular (via Ommaya) cytarabine and etoposide-Gry. Arsenic trioxide synergizes with vincristine, doxorubicin, and etoposide [36,37]. Actinomycin-D was included to re-establish the tumor-suppressive function of TP53 [38]. The intraventricular therapy was based on the MEMMAT protocol (NCT01356290), a Phase II study of metronomic and targeted anti-angiogenesis therapy for children with recurrent/progressive medulloblastoma, that has also shown activity in different pediatric brain tumors [39]. 


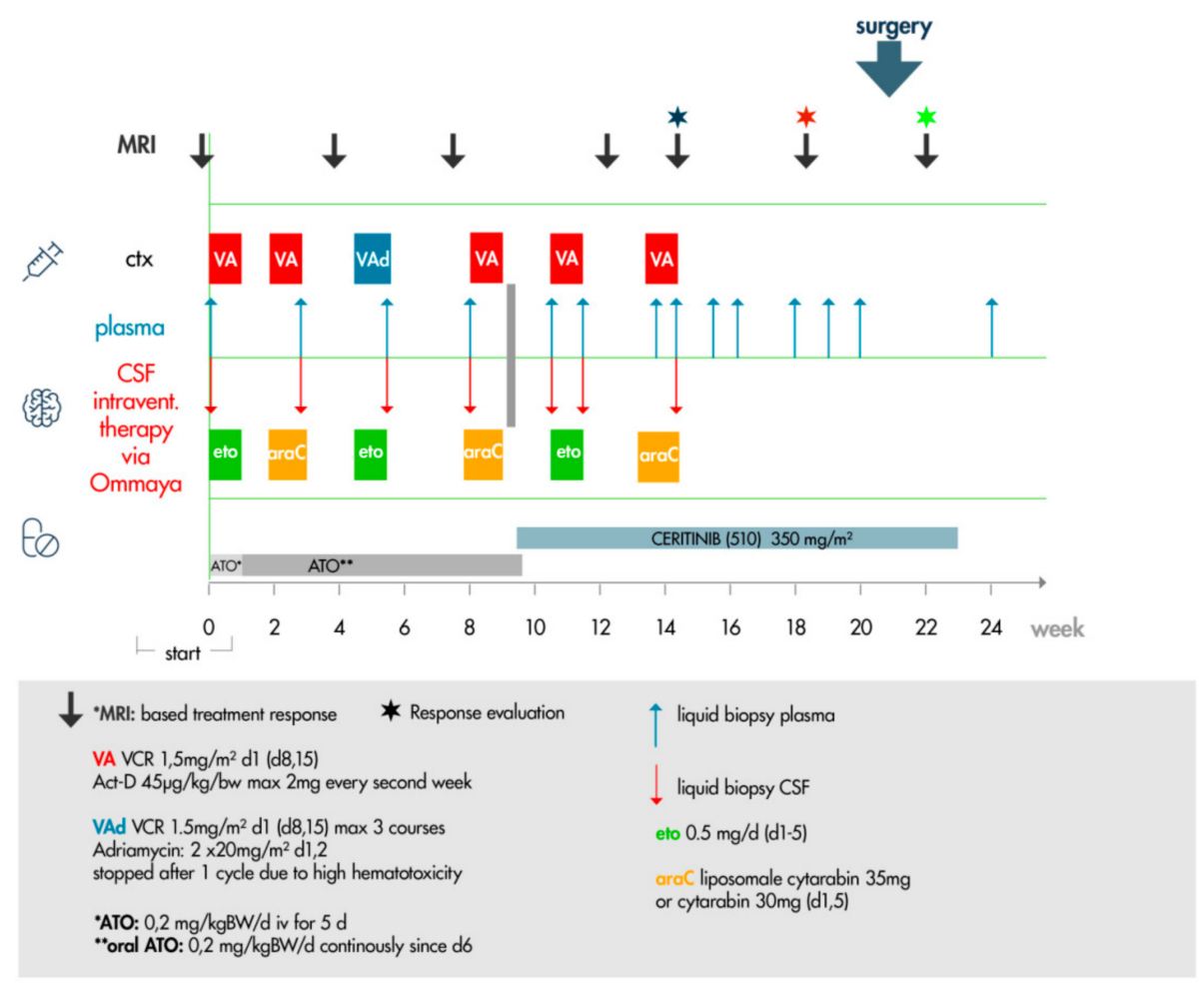

Figure 6. Personalized therapy protocol. Chemotherapy incorporated systemic (ctx) VA (vincristine and actinomycin-D, red) and VAd (adriamycin, blue) blocks, and intraventricular (via Ommaya) cytarabine (araC, yellow) and etoposide-Gry (eto, green). ATO was administered to coincide with the chemotherapy backbone as an intravenous (iv) treatment for 1 week (bright grey), and was subsequently switched to an oral ATO formulation (dark grey). The duration of ATO treatment lasted 68 days (9.7 weeks) in total. Ceritinib was given for 93 days. A metastatic lesion in the cerebellum was detected by MRI after 30 days of ceritinib treatment in combination with VA and intraventricular therapy (blue star). After 30 days of ceritinib monotherapy following the detection of the metastatic relapse, a response to the treatment was confirmed by MRI (red star). Surgical removal of the sanguineous necrotic area was performed (big blue arrow). A third relapse was detected by MRI (green star) two weeks after the detection of the response. The patient died 27 months after initial diagnosis and 3.5 months after the third relapse.

ATO was administered to coincide with the chemotherapy backbone as an intravenous (iv) treatment for 1 week, and was subsequently switched to an oral ATO formulation [40] for a period of approximately 10 weeks in order to forgo hospitalization of the patient. Recently, we have experienced the clinical use of oral ATO in a pediatric brain tumor patient with BCOR alteration [28]. To reach therapeutically efficacious concentrations, we have chosen a higher dose than recommended for the treatment of pediatric patients with APL $(0.2 \mathrm{mg} / \mathrm{kg}$ BW daily versus $0.15 \mathrm{mg} / \mathrm{kg} \mathrm{BW})$. ATO was initially well tolerated intravenously and orally. At week 9, the patient complained about violent leg pain in temporal association to the ATO administration, which was therefore interrupted. At the end of the treatment (67 days), the concentration of ATO was of $3.5 \mu \mathrm{g} / \mathrm{L}$ in the cerebrospinal fluid (CSF) and 30.5 $\mu \mathrm{g} / \mathrm{L}$ in the plasma. This concentration was far below the expected concentration based on data of patients with APL and our own data on HGNET-BCOR [28,41], suggesting an incompliance of the patient due to the side effects, which was confirmed by the mother at a future date.

We switched to ceritinib for approximately 3.5 months. Due to the high malignancy of the disease, we initially decided to maintain the backbone of therapy in parallel to ceritinib for the first four weeks. Furthermore, it was unknown if the efficacy of the ceritinib monotherapy, which was successfully used to target ALK, was equivalent in the context of off-targeting IGF inhibition. The combination of IGF inhibition and chemotherapy is supported by clinical data showing that the inhibition of IGF 
signaling can enhance the effects of chemotherapy [42]. The combined therapy was maintained until the detection of the new cerebellar lesion (blue star in Figure 6). At this point, we decided to apply ceritinib alone. The rationale was on one hand, that no further benefit was observed, and on the other hand, that so far, no clinically proven interaction of ceritinib with chemotherapy was known. Ceritinib has been shown to be effective as monotherapy in brain metastasis of lung cancer (with a median time to intracranial response of 6.1 weeks [43]). Additionally, we intended to improve the quality of life of the patient, avoiding further hospitalization. Ceritinib was applied as opened capsules, dissolving $\mathrm{pH}$-dependent ( $\mathrm{pH}$ 4.2) in commercially available cherry-banana juice according to the staff recommendation of the Hospital for Sick Kids, Toronto, Canada, to facilitate the intake of oral chemotherapy in children. Due to the well-known side effects of nausea and vomiting caused by ceritinib, the patient merely received $350 \mathrm{mg} / \mathrm{m}^{2}$ body surface area in preference to the recommended without-food dosage of $510 \mathrm{mg} / \mathrm{m}^{2}$ body surface area in other pediatric studies (NCT01742286). Beside nausea, no further toxicity related to the ceritinib treatment was observed, including cardiac, liver, lung, or gastrointestinal symptoms, which were investigated weekly by ECG and blood works. After 30 days of ceritinib monotherapy, a response to the treatment was confirmed by MRI (Figure 7). The larger right temporal lesion developed diffuse hemorrhagic transformation under therapy with ceritinib (Figure 7, A/B versus D/E) and was removed surgically 10 days later. Histopathology demonstrated near complete necrosis as well as bleeding with only scattered areas of viable cells. Bleeding and necrosis have been previously described in association with response to IGF1R inhibitors in relapsed malignant astrocytoma and squamous non-small cell lung carcinoma [44,45]. It remains to be clarified if an off-target inhibition by ceritinib is comparable to an inhibition with specific IGF inhibitors in term of adverse events such as hemorrhage. Moreover, a smaller cerebellar lesion has reduced contrast uptake within one month under therapy with ceritinib (Figure 7, C versus F, magnified images). Following the detection of the response by MRI, the patient refused the periodic intake of ceritinib, and post-surgical MRI revealed a third relapse 14 days after the detection of the response. The patient died 27 months after initial diagnosis and 3.5 months after the third relapse.

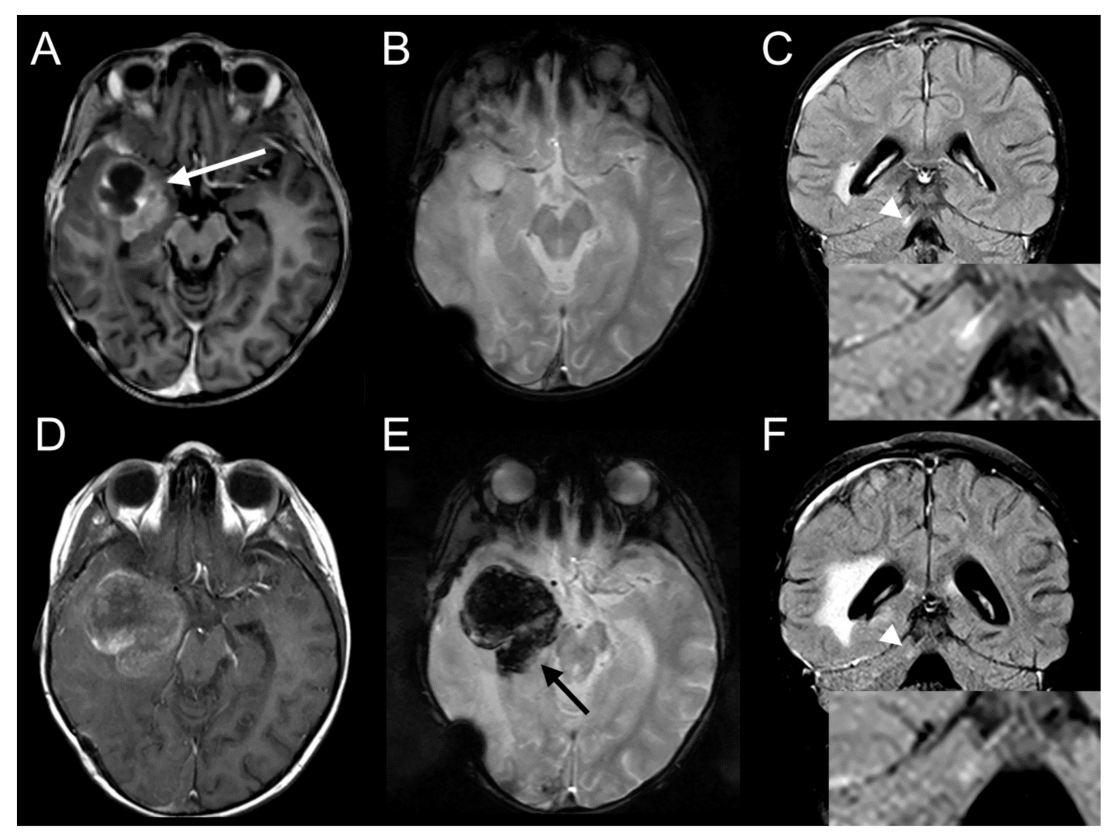

Figure 7. The target lesion is sensitive to the targeted therapy with ceritinib. MRI before therapy with ceritinib (A-C) showing a right sided solid mesiotemporal tumor (A, white arrow) with a cystic component, as well as a contrast media enriching metastatic lesion within the cerebellar folia (C, FLAIR post-contrast media, white arrow head). After 30 days of ceritinib (D-F), the metastatic lesion was regredient (F, FLAIR post-contrast media, white arrow head), and hemorrhagic transformation (E, T2*, black arrow) of the tumor was detected. 


\subsection{Ceritinib Penetrates the Human Brain}

To assess the concentration of ceritinib, we developed and validated an UPLC/MS/MS-based assay. The patient's plasma concentrations reached a peak of $1.70 \mu \mathrm{M}$ after 46 days (the concentration described in the literature is $\sim 1 \mu \mathrm{M}$ [8]). This peak plasma level of ceritinib was observed at time point $\mathrm{d} 12$ before MRI response was detected. Following the detection of the response, the patient refused the periodic intake of the medication, and the plasma level decreased until $0.9 \mu \mathrm{M}$. The post-surgical third relapse followed approximately 2 weeks of markedly diminished ceritinib levels. Interestingly, no ceritinib $(<2.5 \mathrm{ng} / \mathrm{mL})$ was detectable in the CSF samples that were collected in parallel to the plasma samples. However, after the surgical removal of the sanguineous necrotic area, we quantified a ceritinib concentration of $1516 \mathrm{ng} / \mathrm{g}(2.72 \mu \mathrm{M})$ in the isolated tumor areal, while the concentration of ceritinib in the plasma was $0.9 \mu \mathrm{M}$ one day before the surgery. These results indicated that ceritinib was able to cross the blood-brain barrier (BBB) and reached effective concentrations in the tumor.

\section{Discussion}

Numerous challenges remain in the development of molecularly targeted therapies, including the identification of meaningful targets, delivery of agents at the target site, and the determination of response to these agents. This is particular true for pediatric patients in whom underlying germline mutations can contribute to unusual histologies. The percentage of brain cancer in children and adolescents attributable to an underlying genetic syndrome or inherited susceptibility is estimated at $8.6 \%$ [46]. Germline mutations in NOTCH1 cause aortic valve disease [47] and have been found to cause Adams-Oliver syndrome [48]. All these alterations are associated with a downregulation of the Notch signaling, while in our patient, the Notch signaling was upregulated. To our knowledge, NOTCH1 germline mutations have not been associated with cancer so far. However, somatic NOTCH1 mutations have been described in hematopoietic and solid tumors [49-51]. Notably, the Notch pathway is implicated in ependymoma oncogenesis [52], and NOTCH1 mutations have been described to present in $8.3 \%$ of pediatric ependymomas samples in one study [53]. The mutation described here is localized in the EGF-like domain of NOTCH1, which protects NOTCH1 from proteolytic cleavage inhibiting uncontrolled constitutive activation, and governs ligand-induced homodimerization [54]. It remains to be clarified if this mutation was the driver element for the activation of the Notch pathway in the tumor of the patient described in this work. As an alternative, the Notch pathway could also be indirectly activated via the WNT pathway [55]. The germline NOTCH1 mutation was accompanied by a somatic TP53-inactivating mutation. Notably, Notch1 expression results in SHH medulloblastoma formation in p53-deficient mice [56], suggesting a synergistic effect of both mutations in the malignancy of the disease, and a possible cross-talk between the Notch and SHH pathways in the patient's tumor.

Developmental pathways, such as those regulated by IGF, Hedgehog, WNT, and Notch, play key roles in the controls of cell fate decisions during development. A cross-talk among these signaling pathways is typical for cancer stem cells, and targeting embryonic signaling pathways is a current challenge in cancer therapy [57]. In brain tumors, IGF1R is frequently activated in medulloblastoma [3], and INSR and IGF1R are frequently activated in glioblastoma [5]. To date, neither monoclonal antibodies nor small molecule tyrosine kinase inhibitors directed against the IGF pathway have been approved. Ceritinib inhibits kinases such as ROS proto-oncogene 1 (ROS1), INSR, and IGF1R, although it is most active against ALK [9]. Lung cancer patients with brain metastases also respond to the treatment with ceritinib, suggesting that this drug is effective across the BBB [58]. The concentration achieved in the mouse brain after oral administration is low, with a brain-to-plasma ratio below 0.3 [59], but the blood-to-brain exposure ratio of ceritinib in humans is yet to be determined. We were not able to detect ceritinib in the CSF; however, we detected a high concentration in the tumor, suggesting that ceritinib crosses the BBB and is actively transported to the tumor. Ceritinib is a substrate of the efflux transport protein P-gp, which is in discussion to be an effective resistance mechanism against ceritinib [60], and which is located in the BBB [61]. From this point of view, low ceritinib brain concentration appears to be a reasonable consequence. However, the results in this patient reveal about 
doubled ceritinib tumor concentration compared to plasma, although ceritinib was not detectable in the CSF. Leakiness of the BBB has been described, particularly in patients with a WNT-activated brain tumor, and this could explain the effective penetration of ceritinib in the brain in this patient [62]. The accumulation in the tumor rather than in the CSF may be explained by a parallel efficient uptake transport, although it is reported, that ceritinib is not a substrate of breast cancer resistance protein (BCRP), organic cation transporter 1 (OCT1), organic anion transporter 2 (OAT2), or organic anion transporting polypeptide 1 (OATP1) [63]. Therefore, the specific and irreversible binding of ceritinib to so-far unknown intracellular binding sites in the tumor seems to be the most reasonable explanation.

After a first response to ceritinib, the tumor progressed. Although we cannot rule out whether the reduced intake of ceritinib by the patient after detection of the response may have contributed to the progress, it is already known that several mechanisms are associated with the resistance to IGF pathway inhibition. These mechanisms include the compensatory actions of other growth factor receptors [30]. In the tumor of the patient described in this work, other embryonic pathways were upregulated, and it is possible that the tumor cells switched to other signaling to overcome INSR blockade. During the course of disease, the tumor displayed rapid clonal evolution, so that a selection of resistant cell clones is likely. The identification of distinctive mechanisms of resistance in this particular patient is ongoing. In conclusion, here we present the targeting of the IGF receptor INSR using ceritinib in a patient with an incurable neuroepithelial brain tumor. Due to the limitations of our work, which included only one patient with an unknown histology; a systematic investigation of ceritinib for the treatment of IGF-driven tumors in the framework of a clinical study is imperative.

\section{Materials and Methods}

\subsection{Tissue Samples and Cells}

Fresh tumor material from the first relapse (no. 225) was obtained during standard surgery. The RNA of normal brain tissues (adult frontal lobe no. 110 and adult parietal lobe no. 111) was sourced from commercial vendors (Biocat, Heidelberg, Germany). For the isolation of a primary cell culture (225ZL), the fresh tumor sample (no. 225) was disrupted with the GentleMACS Dissociator (Miltenyi Biotec $\mathrm{GmbH}$, Bergisch-Gladbach, Germany), and the cells were dissociated with $0.25 \%$ trypsin. The cells were cultured in DMEM medium containing 10\% human serum, $1 \%$ L-glutamine, and $1 \%$ penicillin-streptomycin (all Sigma-Aldrich, Taufkirchen, Germany). Cell at passage 5 were used for further experiments. This study has been performed in accordance with the ethical standards laid down in the 1964 Declaration of Helsinki and its later amendments. The parents gave their informed consent prior to their inclusion in the study. Formal approval of the local ethics committee for this study was not required, as this was a single case investigation. For details about the ethics, see the supplemental material and methods.

\subsection{Nucleic Acid Extraction}

Tumor samples were analyzed by a pathologist, and regions containing vital tumors were isolated for further processing. DNA from blood and tissues was extracted using a Gentra Puregene Blood Kit (Qiagen, Hilden, Germany). RNA isolation was conducted using the RNeasy Lipid Tissue Mini Kit (Qiagen). RNA was converted to cDNA by using PrimeScript RT Reagent Kit with gDNA Eraser (Takara Bio Europe, Saint-Germain-en-Laye, France). Quality control was performed using a Bioanalyzer2100 (Agilent Technologies, Waldbronn, Germany). Only RNAs with a RIN value $>7$ were used for RNA sequencing analysis and qRT-PCR.

\subsection{DNA Sequencing}

PCR products were sequenced using an ABI Prism 3100 Genetic Analyzer and the BigDye v3 Terminator Kit (Thermo Fisher, Dreieich, Germany). The sequences were compared to the reference sequence using the Sequencher program (Gene Codes, Corp., Ann Arbor, 
MI, USA). The following primers were used: NOTCH1: 5'- GATGTCAACGAGTGTGGCCA and 5'- AGTTCCGGGAAACTCCAGAGA; TP53: 5'- GCTTGCCACAGGTCTCCC and 5'- GAGGCAAGCAGAGGCTGG.

\section{4. $q R T-P C R$}

qRT-PCR was performed using the Light Cycler 480 II detection system and software (Applied Biosystems, Darmstadt, Germany) with a KAPA SYBR FAST Light Cycler 480 Kit (PeqLab, Erlangen, Germany). The following primers were used: AXIN2: 5'-GCTCAGAGCTTGACCCTGG and $5^{\prime}-$ TCATACATCGGGAGCACCGT; HPRT1: 5'-TGACACTGGCAAAACAATGCA and 5'-GGTCCTTTTCACCAGCAAGCT. GLI2: 5' -TCCACACACGCGGAACACCA and $5^{\prime}$ - CAGCTGGCTCAGCATGGTCA, HES4: 5'-GTGCAGGTGACGGCCGC and 5'- CGGCCAGGAAGCGGTTCA.

\subsection{RNA Sequencing}

Libraries were constructed using the TruSeq mRNA stranded protocol (Illumina, San Diego, CA, USA) using $2 \mu \mathrm{g}$ of total RNA. Pair-end sequencing with a read length of $150 \mathrm{bps}$ was performed on a NextSeq500 Instrument (Illumina, San Diego, CA, USA). A total of 50 million reads per library were produced. Read mapping was performed using the TopHat2 v2.0.7 aligner [64] and the Homo sapiens UCSC hg19 reference genome (RefSeq gene annotations). The FPKM values of reference genes and transcripts were estimated by Cufflinks 2.0.5 [65]. TPM values of genes and transcripts were calculated according to Lior Pachter (https://arxiv.org/abs/1104.3889). Ingenuity pathway analysis (IPA; Ingenuity Systems/Qiagen, Redwood City, CA, USA) was used to map lists of significant genes to biological pathways. To identify mutations, data were processed using BWA Enrichment v1.0 for the generation of BAM files and GATK for variant calling. Translocation was identified with TopHat-Fusions [66]. Analysis of variants was performed with the VariantStudio software (Illumina, San Diego, CA, USA).

\subsection{Methylation Analysis and Copy Number Variation Profiles}

DNA methylation analyses were performed using an EPIC 850k DNA methylome bead array (Illumina, San Diego, CA, USA). We used standard protocols for tissue and DNA processing. Hybridization and processing of the chip was performed as indicated by the manufacturer. Data were preprocessed using Illumina Genome Studio; further analysis was performed after uploading raw data (idat files) onto the platform MolecularNeuroPathology.org 2018 version 3.1.2, which provides brain tumor classifier results (version v11b4) and copy number variation profiles. Furthermore, we compared the DNA methylation profiles of the unclassified tumor specimens with tumor tissue deriving from common childhood brain tumor entities by applying principal component analysis using the $\mathrm{R}$ package "RnBeads" [67].

\subsection{Cellular Proliferation Assays}

Linsitinib, vismodegib, and ceritinib (Selleck Chemicals, Houston, TX, USA) were dissolved in DMSO (Sigma-Aldrich, Taufkirchen, Germany) to a final concentration of $10 \mathrm{mM}$. Arsenic trioxide (ATO) was prepared as previously described [68]. 225ZL cells were plated in triplicates at a density of 5000 cells/well in a 96-well plate, and incubated with the different drugs. Viable cells were quantified using the cell proliferation reagent WST-1 (Roche, Mannheim, Germany).

\subsection{Phosphorylation Assay}

225ZL cells were grown in charcoal-stripped (Sigma-Aldrich, Taufkirchen, Germany) DMEM supplemented with $10 \%$ human serum, $2 \mathrm{mM}$ of L-Glutamine, $1 \mathrm{mM}$ of sodium pyruvate, and penicillin-streptomycin for 1 day. The cells were serum-starved for $24 \mathrm{~h}$, and then treated with $1 \mu \mathrm{M}$ of ceritinib for two hours, followed by incubation with $20 \mathrm{ng} / \mathrm{mL}$ of IGF2 for $15 \mathrm{~min}$. Cell 
lysates were loaded on SDS-PAGE gels, followed by blotting to a polyvinylidene difluoride membrane (BioRad Laboratories, Inc., Hercules, CA, USA). The following antibodies were obtained from Cell Signaling Technology (Cambridge, UK): GAPDH (14C10) (cat \# 2118, 1:1000 dilution), IGF1 receptor $\beta$ (D23H3) XP ${ }^{\circledR}$ (cat \# 9750, 1:1000 dilution) and phospho-IGF1 receptor $\beta$ (Tyr1131)/Insulin Receptor $\beta$ (Tyr1146) (cat \# 3021, 1:1000 dilution). Detection was done by a SuperSignal ${ }^{\text {TM }}$ West Dura Extended Duration Substrate (Thermo Fisher Scientific, Waltham, MA, USA), and the imaging was performed on Fusion Pulse TS (Vilber Lourmat, Eberhardzell, Germany).

\subsection{Targeted Therapy Protocol}

The patient was enrolled for genomic profiling following the parent's informed consent. Tumor and blood samples were then acquired, processed, molecularly profiled, and analyzed computationally. Molecular results were reviewed in the in-house pediatric tumor board. No early-phase clinical trial was available for this patient. The parents have been informed of all the disease and treatment-related relevant molecular results. Targeted therapy was initiated following parent's consent regarding compassionate and off-label use. For protocol details, see the results section.

\subsection{Arsenic Concentration}

The total arsenic concentration in CSF and plasma was analyzed as described in [28].

\subsection{Ceritinib Quantification}

Ceritinib concentration in plasma, CSF, and tumor tissue was quantified using UPLC-MS/MSand liquid/liquid extraction techniques. For quantification in the tumor tissue, regions containing vital tumors were isolated from the surrounding necrotic regions by a pathologist. The plasma, CSF, and tissue samples were spiked with internal standards d7-ceritinib and boric buffer $\mathrm{pH} 9(50 \mu \mathrm{L})$. Subsequently tert-butylmethylether was added, shaken for $10 \mathrm{~min}$, and centrifuged (10 min, $3000 \mathrm{~g}$ ). The supernatants were evaporated to dryness in a stream of nitrogen at $40{ }^{\circ} \mathrm{C}$, reconstituted by adding LC eluent $(100 \mu \mathrm{L})$, and injected $(20 \mu \mathrm{L})$ into the UPLC-MS/MS system, which consisted of an Acquity sample manager, an Acquity solvent manager, and a TQD triple stage quadrupole mass spectrometer (Waters GmbH, Eschborn, Germany). For chromatographic separation, an Acquity CSH C18 (1.7 $\mu \mathrm{m}$; $2.1 \times 50 \mathrm{~mm}$ ) column (Waters $\mathrm{GmbH}$, Eschborn, Germany) at $40{ }^{\circ} \mathrm{C}$ was used. The eluent consisted of water, including $0.01 \%$ formic and $5 \%$ acetonitrile (A) and acetonitrile including $0.01 \%$ formic acid (B). For separation a gradient program at $0.5 \mathrm{~mL} / \mathrm{min}$ was applied. From 0 to $0.5 \mathrm{~min}, 95 \% \mathrm{~A} / 5 \% \mathrm{~B}$ was used. From 0.5 to $2.5 \mathrm{~min}$, the ratio was linearly changed to $5 \% \mathrm{~A} / 95 \% \mathrm{~B}$ and held for $3.5 \mathrm{~min}$. The eluent was introduced directly into the electrospray ion source of the tandem mass spectrometer (MS/MS). The MS/MS transitions monitored in the positive ion mode were $\mathrm{m} / \mathrm{z} 558.1 \rightarrow \mathrm{m} / \mathrm{z} 84.0$ at 38 $\mathrm{V}$ for ceritinib and $\mathrm{m} / \mathrm{z} 565.1 \rightarrow \mathrm{m} / \mathrm{z} 84.0$ at $38 \mathrm{~V}$ for $\mathrm{d} 7$-ceritinib. The assay was validated according to common FDA and European Medicines Agency (EMA) validation guidelines on bioanalytical method validation. The lower limit of quantification of ceritinib was $2.5 \mathrm{ng} / \mathrm{mL}$. The calibrated range was $2.5-1000 \mathrm{ng} / \mathrm{mL}(4.5-1790 \mathrm{nM})$ with correlation coefficients $>0.995$. The overall accuracy varied between $-2.3 \%$ and $+5.2 \%$, and an overall precision ranging from $2.3 \%$ to $12.4 \%$.

Supplementary Materials: Supplementary materials can be found at http://www.mdpi.com/1422-0067/20/17/ 4267/s1.

Author Contributions: Conceptualization, A.R., C.P. and J.F.; methodology, J.B., M.F., P.N.H., K.F.; investigation, H.B., S.H., W.W., M.G., K.F., N.L., N.B., L.R., L.S., C.S., M.A.B., T.P., M.A.N., F.A., A.W.; resources, W.W., M.G., C.S.; writing-original draft preparation, A.R. and C.P.; writing-review and editing, F.A., J.B., M.F., W.W., M.G., H.B., S.H., N.L., N.B., L.R., L.S., C.S., T.P., M.A.N., A.W., M.A.B., P.N.H., K.F., J.F.; visualization, A.R., C.P., S.H., K.F., C.S., M.A.B.; supervision, J.F.; project administration, C.P.

Funding: This research received no external funding.

Conflicts of Interest: The authors declare no conflict of interest. 


\section{Abbreviations}

$\begin{array}{ll}\text { Act-D } & \text { dactinomycin/ actinomycin-D } \\ \text { araC } & \text { cytarabine } \\ \text { ATO } & \text { arsenic trioxide } \\ \text { BBB } & \text { Blood-brain barrier } \\ \text { BCC } & \text { basal cell carcinoma } \\ \text { CSF } & \text { cerebrospinal fluid } \\ \text { Eto } & \text { etoposide } \\ \text { HGNET-BCOR } & \text { High grade neuroepithelial tumor with BCOR alteration } \\ \text { IGF } & \text { insulin-like growth factor } \\ \text { IPA } & \text { Ingenuity Pathway Analysis } \\ \text { iv } & \text { intravenous } \\ \text { MRI } & \text { magnetic resonance imaging } \\ \text { RNA seq } & \text { whole-transcriptome sequencing } \\ \text { ROS1 } & \text { proto-oncogene receptor tyrosine kinase } \\ \text { SHH } & \text { sonic hedgehog } \\ \text { TPM } & \text { transcripts per kilobase million } \\ \text { VCR } & \text { vincristine }\end{array}$

\section{References}

1. Lodhia, K.A.; Tienchaiananda, P.; Haluska, P. Understanding the Key to Targeting the IGF Axis in Cancer: A Biomarker Assessment. Front. Oncol. 2015, 5, 142. [CrossRef] [PubMed]

2. Bondy, C.A.; Lee, W.H. Patterns of insulin-like growth factor and IGF receptor gene expression in the brain. Functional implications. Ann. N. Y. Acad. Sci. 1993, 692, 33-43. [CrossRef] [PubMed]

3. Del Valle, L.; Enam, S.; Lassak, A.; Wang, J.Y.; Croul, S.; Khalili, K.; Reiss, K. Insulin-like growth factor I receptor activity in human medulloblastomas. Clin. Cancer Res. 2002, 8, 1822-1830. [PubMed]

4. Hartmann, W.; Koch, A.; Brune, H.; Waha, A.; Schuller, U.; Dani, I.; Denkhaus, D.; Langmann, W.; Bode, U.; Wiestler, O.D.; et al. Insulin-like growth factor II is involved in the proliferation control of medulloblastoma and its cerebellar precursor cells. Am. J. Pathol. 2005, 166, 1153-1162. [CrossRef]

5. Gong, Y.; Ma, Y.; Sinyuk, M.; Loganathan, S.; Thompson, R.C.; Sarkaria, J.N.; Chen, W.; Lathia, J.D.; Mobley, B.C.; Clark, S.W.; et al. Insulin-mediated signaling promotes proliferation and survival of glioblastoma through Akt activation. Neuro Oncol. 2016, 18, 48-57. [CrossRef]

6. Korshunov, A.; Neben, K.; Wrobel, G.; Tews, B.; Benner, A.; Hahn, M.; Golanov, A.; Lichter, P. Gene expression patterns in ependymomas correlate with tumor location, grade, and patient age. Am. J. Pathol. 2003, 163, 1721-1727. [CrossRef]

7. Simpson, A.; Petnga, W.; Macaulay, V.M.; Weyer-Czernilofsky, U.; Bogenrieder, T. Insulin-Like Growth Factor (IGF) Pathway Targeting in Cancer: Role of the IGF Axis and Opportunities for Future Combination Studies. Target. Oncol. 2017, 12, 571-597. [CrossRef]

8. Shaw, A.T.; Kim, D.W.; Mehra, R.; Tan, D.S.; Felip, E.; Chow, L.Q.; Camidge, D.R.; Vansteenkiste, J.; Sharma, S.; De Pas, T.; et al. Ceritinib in ALK-rearranged non-small-cell lung cancer. N. Engl. J. Med. 2014, 370, 1189-1197. [CrossRef]

9. Marsilje, T.H.; Pei, W.; Chen, B.; Lu, W.; Uno, T.; Jin, Y.; Jiang, T.; Kim, S.; Li, N.; Warmuth, M.; et al. Synthesis, structure-activity relationships, and in vivo efficacy of the novel potent and selective anaplastic lymphoma kinase (ALK) inhibitor 5-chloro-N2-(2-isopropoxy-5-methyl-4-(piperidin-4-yl)phenyl)-N4-(2-(isopropylsulf onyl)phenyl)pyrimidine-2,4-diamine (LDK378) currently in phase 1 and phase 2 clinical trials. J. Med. Chem. 2013, 56, 5675-5690. [CrossRef]

10. Van Erp, A.E.M.; Hillebrandt-Roeffen, M.H.S.; van Houdt, L.; Fleuren, E.D.G.; van der Graaf, W.T.A.; Versleijen-Jonkers, Y.M.H. Targeting Anaplastic Lymphoma Kinase (ALK) in Rhabdomyosarcoma (RMS) with the Second-Generation ALK Inhibitor Ceritinib. Target. Oncol. 2017, 12, 815-826. [CrossRef]

11. Vewinger, N.; Huprich, S.; Seidmann, L.; Russo, A.; Alt, F.; Bender, H.; Sommer, C.; Samuel, D.; Lehmann, N.; Backes, N.; et al. IGF1R Is a Potential New Therapeutic Target for HGNET-BCOR Brain Tumor Patients. Int. J. Mol. Sci. 2019, 20, 3027. [CrossRef] [PubMed] 
12. Gessi, M.; Giagnacovo, M.; Modena, P.; Elefante, G.; Gianno, F.; Buttarelli, F.R.; Arcella, A.; Donofrio, V.; Camassei, F.D.; Nozza, P.; et al. Role of Immunohistochemistry in the Identification of Supratentorial C11ORF95-RELA Fused Ependymoma in Routine Neuropathology. Am. J. Surg. Pathol. 2019, 43, 56-63. [CrossRef] [PubMed]

13. Capper, D.; Jones, D.T.W.; Sill, M.; Hovestadt, V.; Schrimpf, D.; Sturm, D.; Koelsche, C.; Sahm, F.; Chavez, L.; Reuss, D.E.; et al. DNA methylation-based classification of central nervous system tumours. Nature 2018, 555, 469-474. [CrossRef] [PubMed]

14. Yang, S.H.; Andl, T.; Grachtchouk, V.; Wang, A.; Liu, J.; Syu, L.J.; Ferris, J.; Wang, T.S.; Glick, A.B.; Millar, S.E.; et al. Pathological responses to oncogenic Hedgehog signaling in skin are dependent on canonical Wnt/beta3-catenin signaling. Nat. Genet. 2008, 40, 1130-1135. [CrossRef] [PubMed]

15. Suzuki, N.; Hajicek, N.; Kozasa, T. Regulation and physiological functions of G12/13-mediated signaling pathways. Neurosignals 2009, 17, 55-70. [CrossRef] [PubMed]

16. Atkinson, J.M.; Shelat, A.A.; Carcaboso, A.M.; Kranenburg, T.A.; Arnold, L.A.; Boulos, N.; Wright, K.; Johnson, R.A.; Poppleton, H.; Mohankumar, K.M.; et al. An integrated in vitro and in vivo high-throughput screen identifies treatment leads for ependymoma. Cancer Cell 2011, 20, 384-399. [CrossRef]

17. Pietsch, T.; Wohlers, I.; Goschzik, T.; Dreschmann, V.; Denkhaus, D.; Dorner, E.; Rahmann, S.; Klein-Hitpass, L. Supratentorial ependymomas of childhood carry C11orf95-RELA fusions leading to pathological activation of the NF-kappaB signaling pathway. Acta Neuropathol. 2014, 127, 609-611. [CrossRef]

18. Giovannone, B.; Lee, E.; Laviola, L.; Giorgino, F.; Cleveland, K.A.; Smith, R.J. Two novel proteins that are linked to insulin-like growth factor (IGF-I) receptors by the Grb10 adapter and modulate IGF-I signaling. J. Biol. Chem. 2003, 278, 31564-31573. [CrossRef]

19. Gao, J.; Aksoy, B.A.; Dogrusoz, U.; Dresdner, G.; Gross, B.; Sumer, S.O.; Sun, Y.; Jacobsen, A.; Sinha, R.; Larsson, E.; et al. Integrative analysis of complex cancer genomics and clinical profiles using the cBioPortal. Sci. Signal. 2013, 6, pl1. [CrossRef]

20. Adzhubei, I.A.; Schmidt, S.; Peshkin, L.; Ramensky, V.E.; Gerasimova, A.; Bork, P.; Kondrashov, A.S.; Sunyaev, S.R. A method and server for predicting damaging missense mutations. Nat. Methods 2010, 7, 248-249. [CrossRef]

21. Zehir, A.; Benayed, R.; Shah, R.H.; Syed, A.; Middha, S.; Kim, H.R.; Srinivasan, P.; Gao, J.; Chakravarty, D.; Devlin, S.M.; et al. Mutational landscape of metastatic cancer revealed from prospective clinical sequencing of 10,000 patients. Nat. Med. 2017, 23, 703. [CrossRef] [PubMed]

22. Landrum, M.J.; Lee, J.M.; Riley, G.R.; Jang, W.; Rubinstein, W.S.; Church, D.M.; Maglott, D.R. ClinVar: Public archive of relationships among sequence variation and human phenotype. Nucleic Acids Res. 2014, 42, D980-D985. [CrossRef] [PubMed]

23. Regairaz, M.; Munier, F.; Sartelet, H.; Castaing, M.; Marty, V.; Renauleaud, C.; Doux, C.; Delbe, J.; Courty, J.; Fabre, M.; et al. Mutation-Independent Activation of the Anaplastic Lymphoma Kinase in Neuroblastoma. Am. J. Pathol. 2016, 186, 435-445. [CrossRef] [PubMed]

24. Kahn, M. Can we safely target the WNT pathway? Nat. Rev. Drug Discov. 2014, 13, 513-532. [CrossRef] [PubMed]

25. Ryeom, S.W. The cautionary tale of side effects of chronic Notch1 inhibition. J. Clin. Investig. 2011, 121, 508-509. [CrossRef]

26. Fellner, C. Vismodegib (erivedge) for advanced Basal cell carcinoma. Pharm. Ther. 2012, 37, 670-682.

27. Beauchamp, E.M.; Ringer, L.; Bulut, G.; Sajwan, K.P.; Hall, M.D.; Lee, Y.C.; Peaceman, D.; Ozdemirli, M.; Rodriguez, O.; Macdonald, T.J.; et al. Arsenic trioxide inhibits human cancer cell growth and tumor development in mice by blocking Hedgehog/GLI pathway. J. Clin. Investig. 2011, 121, 148-160. [CrossRef]

28. Paret, C.; Russo, A.; Otto, H.; Mayer, A.; Zahnreich, S.; Wagner, W.; Samuel, D.; Scharnhorst, D.; Solomon, D.A.; Dhall, G.; et al. Personalized therapy: CNS HGNET-BCOR responsiveness to arsenic trioxide combined with radiotherapy. Oncotarget 2017, 8, 114210-114225. [CrossRef]

29. Torka, P.; Al Ustwani, O.; Wetzler, M.; Wang, E.S.; Griffiths, E.A. Swallowing a bitter pill-oral arsenic trioxide for acute promyelocytic leukemia. Blood Rev. 2016, 30, 201-211. [CrossRef]

30. Beckwith, H.; Yee, D. Minireview: Were the IGF Signaling Inhibitors All Bad? Mol. Endocrinol. 2015, 29, 1549-1557. [CrossRef] 
31. Mulvihill, M.J.; Cooke, A.; Rosenfeld-Franklin, M.; Buck, E.; Foreman, K.; Landfair, D.; O'Connor, M.; Pirritt, C.; Sun, Y.; Yao, Y.; et al. Discovery of OSI-906: A selective and orally efficacious dual inhibitor of the IGF-1 receptor and insulin receptor. Future Med. Chem. 2009, 1, 1153-1171. [CrossRef] [PubMed]

32. Poondru, S.; Chaves, J.; Yuen, G.; Parker, B.; Conklin, E.; Singh, M.; Nagata, M.; Gill, S. Mass balance, pharmacokinetics, and metabolism of linsitinib in cancer patients. Cancer Chemother. Pharmacol. 2016, 77, 829-837. [CrossRef] [PubMed]

33. Shahi, M.H.; Rey, J.A.; Castresana, J.S. The sonic hedgehog-GLI1 signaling pathway in brain tumor development. Expert Opin. Ther. Targets 2012, 16, 1227-1238. [CrossRef] [PubMed]

34. Kimura, H.; Ng, J.M.; Curran, T. Transient inhibition of the Hedgehog pathway in young mice causes permanent defects in bone structure. Cancer Cell 2008, 13, 249-260. [CrossRef] [PubMed]

35. Robinson, G.W.; Kaste, S.C.; Chemaitilly, W.; Bowers, D.C.; Laughton, S.; Smith, A.; Gottardo, N.G.; Partap, S.; Bendel, A.; Wright, K.D.; et al. Irreversible growth plate fusions in children with medulloblastoma treated with a targeted hedgehog pathway inhibitor. Oncotarget 2017, 8, 69295-69302. [CrossRef] [PubMed]

36. Boehme, K.A.; Nitsch, J.; Riester, R.; Handgretinger, R.; Schleicher, S.B.; Kluba, T.; Traub, F. Arsenic trioxide potentiates the effectiveness of etoposide in Ewing sarcomas. Int. J. Oncol. 2016, 49, 2135-2146. [CrossRef]

37. Meister, M.T.; Boedicker, C.; Graab, U.; Hugle, M.; Hahn, H.; Klingebiel, T.; Fulda, S. Arsenic trioxide induces Noxa-dependent apoptosis in rhabdomyosarcoma cells and synergizes with antimicrotubule drugs. Cancer Lett. 2016, 381, 287-295. [CrossRef]

38. Tzaridis, T.; Milde, T.; Pajtler, K.W.; Bender, S.; Jones, D.T.; Muller, S.; Wittmann, A.; Schlotter, M.; Kulozik, A.E.; Lichter, P.; et al. Low-dose Actinomycin-D treatment re-establishes the tumoursuppressive function of P53 in RELA-positive ependymoma. Oncotarget 2016, 7, 61860-61873. [CrossRef]

39. Slavc, I.; Peyrl, A.; Chocholous, M.; Reisinger, D.; Mayr, L.; Azizi, A.; Dieckmann, K.; Haberler, C.; Czech, T. MBCL-27. RESPONSE OF RECURRENT MALIGNANT CHILDHOOD CNS TUMORS TO A MEMMAT BASED METRONOMIC ANTIANGIOGENIC COMBINATION THERAPY VARIES DEPENDENT ON TUMOR TYPE: EXPERIENCE IN 71 PATIENTS. Neuro Oncol. 2018, 20, i122. [CrossRef]

40. Kumana, C.R.; Au, W.Y.; Lee, N.S.; Kou, M.; Mak, R.W.; Lam, C.W.; Kwong, Y.L. Systemic availability of arsenic from oral arsenic-trioxide used to treat patients with hematological malignancies. Eur. J. Clin. Pharmacol. 2002, 58, 521-526. [CrossRef]

41. Kiguchi, T.; Yoshino, Y.; Yuan, B.; Yoshizawa, S.; Kitahara, T.; Akahane, D.; Gotoh, M.; Kaise, T.; Toyoda, H.; Ohyashiki, K. Speciation of arsenic trioxide penetrates into cerebrospinal fluid in patients with acute promyelocytic leukemia. Leuk. Res. 2010, 34, 403-405. [CrossRef] [PubMed]

42. Macaulay, V.M.; Middleton, M.R.; Protheroe, A.S.; Tolcher, A.; Dieras, V.; Sessa, C.; Bahleda, R.; Blay, J.Y.; LoRusso, P.; Mery-Mignard, D.; et al. Phase I study of humanized monoclonal antibody AVE1642 directed against the type 1 insulin-like growth factor receptor (IGF-1R), administered in combination with anticancer therapies to patients with advanced solid tumors. Ann. Oncol. 2013, 24, 784-791. [CrossRef] [PubMed]

43. Kim, D.W.; Mehra, R.; Tan, D.S.; Felip, E.; Chow, L.Q.; Camidge, D.R.; Vansteenkiste, J.; Sharma, S.; De Pas, T.; Riely, G.J.; et al. Activity and safety of ceritinib in patients with ALK-rearranged non-small-cell lung cancer (ASCEND-1): Updated results from the multicentre, open-label, phase 1 trial. Lancet Oncol. 2016, 17, 452-463. [CrossRef]

44. Aiken, R.; Axelson, M.; Harmenberg, J.; Klockare, M.; Larsson, O.; Wassberg, C. Phase I clinical trial of AXL1717 for treatment of relapsed malignant astrocytomas: Analysis of dose and response. Oncotarget 2017, 8, 81501-81510. [CrossRef] [PubMed]

45. Ekman, S.; Frodin, J.E.; Harmenberg, J.; Bergman, A.; Hedlund, A.; Dahg, P.; Alvfors, C.; Stahl, B.; Bergstrom, S.; Bergqvist, M. Clinical Phase I study with an Insulin-like Growth Factor-1 receptor inhibitor: Experiences in patients with squamous non-small cell lung carcinoma. Acta Oncol. 2011, 50, 441-447. [CrossRef] [PubMed]

46. Zhang, J.; Walsh, M.F.; Wu, G.; Edmonson, M.N.; Gruber, T.A.; Easton, J.; Hedges, D.; Ma, X.; Zhou, X.; Yergeau, D.A.; et al. Germline Mutations in Predisposition Genes in Pediatric Cancer. N. Engl. J. Med. 2015, 373, 2336-2346. [CrossRef] [PubMed]

47. Garg, V.; Muth, A.N.; Ransom, J.F.; Schluterman, M.K.; Barnes, R.; King, I.N.; Grossfeld, P.D.; Srivastava, D. Mutations in NOTCH1 cause aortic valve disease. Nature 2005, 437, 270-274. [CrossRef] 
48. Southgate, L.; Sukalo, M.; Karountzos, A.S.V.; Taylor, E.J.; Collinson, C.S.; Ruddy, D.; Snape, K.M.; Dallapiccola, B.; Tolmie, J.L.; Joss, S.; et al. Haploinsufficiency of the NOTCH1 Receptor as a Cause of Adams-Oliver Syndrome With Variable Cardiac Anomalies. Circ. Cardiovasc. Genet. 2015, 8, 572-581. [CrossRef]

49. Weng, A.P.; Ferrando, A.A.; Lee, W.; Morris, J.P.; Silverman, L.B.; Sanchez-Irizarry, C.; Blacklow, S.C.; Look, A.T.; Aster, J.C. Activating mutations of NOTCH1 in human T cell acute lymphoblastic leukemia. Science 2004, 306, 269-271. [CrossRef]

50. Westhoff, B.; Colaluca, I.N.; D’Ario, G.; Donzelli, M.; Tosoni, D.; Volorio, S.; Pelosi, G.; Spaggiari, L.; Mazzarol, G.; Viale, G.; et al. Alterations of the Notch pathway in lung cancer. Proc. Natl. Acad. Sci. USA 2009, 106, 22293-22298. [CrossRef]

51. Wang, N.J.; Sanborn, Z.; Arnett, K.L.; Bayston, L.J.; Liao, W.; Proby, C.M.; Leigh, I.M.; Collisson, E.A.; Gordon, P.B.; Jakkula, L.; et al. Loss-of-function mutations in Notch receptors in cutaneous and lung squamous cell carcinoma. Proc. Natl. Acad. Sci. USA 2011, 108, 17761-17766. [CrossRef] [PubMed]

52. Modena, P.; Lualdi, E.; Facchinetti, F.; Veltman, J.; Reid, J.F.; Minardi, S.; Janssen, I.; Giangaspero, F.; Forni, M.; Finocchiaro, G.; et al. Identification of tumor-specific molecular signatures in intracranial ependymoma and association with clinical characteristics. J. Clin. Oncol. 2006, 24, 5223-5233. [CrossRef] [PubMed]

53. Puget, S.; Grill, J.; Valent, A.; Bieche, I.; Dantas-Barbosa, C.; Kauffmann, A.; Dessen, P.; Lacroix, L.; Geoerger, B.; Job, B.; et al. Candidate genes on chromosome 9q33-34 involved in the progression of childhood ependymomas. J. Clin. Oncol. 2009, 27, 1884-1892. [CrossRef] [PubMed]

54. Sakamoto, K.; Chao, W.S.; Katsube, K.; Yamaguchi, A. Distinct roles of EGF repeats for the Notch signaling system. Exp. Cell Res. 2005, 302, 281-291. [CrossRef] [PubMed]

55. Rodilla, V.; Villanueva, A.; Obrador-Hevia, A.; Robert-Moreno, A.; Fernandez-Majada, V.; Grilli, A.; Lopez-Bigas, N.; Bellora, N.; Alba, M.M.; Torres, F.; et al. Jagged1 is the pathological link between Wnt and Notch pathways in colorectal cancer. Proc. Natl. Acad. Sci. USA 2009, 106, 6315-6320. [CrossRef] [PubMed]

56. Natarajan, S.; Li, Y.; Miller, E.E.; Shih, D.J.; Taylor, M.D.; Stearns, T.M.; Bronson, R.T.; Ackerman, S.L.; Yoon, J.K.; Yun, K. Notch1-induced brain tumor models the sonic hedgehog subgroup of human medulloblastoma. Cancer Res. 2013, 73, 5381-5390. [CrossRef]

57. Takebe, N.; Miele, L.; Harris, P.J.; Jeong, W.; Bando, H.; Kahn, M.; Yang, S.X.; Ivy, S.P. Targeting Notch, Hedgehog, and Wnt pathways in cancer stem cells: Clinical update. Nat. Rev. Clin. Oncol. 2015, 12, 445-464. [CrossRef]

58. Zhu, Z.; Chai, Y. Crizotinib resistance overcome by ceritinib in an ALK-positive non-small cell lung cancer patient with brain metastases: A case report. Medicine 2017, 96, e8652. [CrossRef]

59. Kort, A.; Sparidans, R.W.; Wagenaar, E.; Beijnen, J.H.; Schinkel, A.H. Brain accumulation of the EML4-ALK inhibitor ceritinib is restricted by P-glycoprotein (P-GP/ABCB1) and breast cancer resistance protein (BCRP/ABCG2). Pharmacol. Res. 2015, 102, 200-207. [CrossRef]

60. Katayama, R.; Sakashita, T.; Yanagitani, N.; Ninomiya, H.; Horiike, A.; Friboulet, L.; Gainor, J.F.; Motoi, N.; Dobashi, A.; Sakata, S.; et al. P-glycoprotein Mediates Ceritinib Resistance in Anaplastic Lymphoma Kinase-rearranged Non-small Cell Lung Cancer. EBioMedicine 2016, 3, 54-66. [CrossRef]

61. Fromm, M.F. Importance of P-glycoprotein at blood-tissue barriers. Trends Pharmacol. Sci. 2004, 25, 423-429. [CrossRef] [PubMed]

62. Phoenix, T.N.; Patmore, D.M.; Boop, S.; Boulos, N.; Jacus, M.O.; Patel, Y.T.; Roussel, M.F.; Finkelstein, D.; Goumnerova, L.; Perreault, S.; et al. Medulloblastoma Genotype Dictates Blood Brain Barrier Phenotype. Cancer Cell 2016, 29, 508-522. [CrossRef] [PubMed]

63. Santarpia, M.; Daffina, M.G.; D’Aveni, A.; Marabello, G.; Liguori, A.; Giovannetti, E.; Karachaliou, N.; Cao, M.G.; Rosell, R.; Altavilla, G. Spotlight on ceritinib in the treatment of ALK+ NSCLC: Design, development and place in therapy. Drug Des. Dev. Ther. 2017, 11, 2047-2063. [CrossRef] [PubMed]

64. Kim, D.; Pertea, G.; Trapnell, C.; Pimentel, H.; Kelley, R.; Salzberg, S.L. TopHat2: Accurate alignment of transcriptomes in the presence of insertions, deletions and gene fusions. Genome Biol. 2013, 14, R36. [CrossRef] [PubMed]

65. Trapnell, C.; Williams, B.A.; Pertea, G.; Mortazavi, A.; Kwan, G.; van Baren, M.J.; Salzberg, S.L.; Wold, B.J.; Pachter, L. Transcript assembly and quantification by RNA-Seq reveals unannotated transcripts and isoform switching during cell differentiation. Nat. Biotechnol. 2010, 28, 511-515. [CrossRef] 
66. Kim, D.; Salzberg, S.L. TopHat-Fusion: An algorithm for discovery of novel fusion transcripts. Genome Biol. 2011, 12, R72. [CrossRef]

67. Assenov, Y.; Müller, F.; Lutsik, P.; Walter, J.; Lengauer, T.; Bock, C. Comprehensive analysis of DNA methylation data with RnBeads. Nat. Methods 2014, 11, 1138. [CrossRef]

68. Paret, C.; Theruvath, J.; Russo, A.; Kron, B.; El Malki, K.; Lehmann, N.; Wingerter, A.; Neu, M.A.; Gerhold-Ay, A.; Wagner, W.; et al. Activation of the basal cell carcinoma pathway in a patient with CNS HGNET-BCOR diagnosis: Consequences for personalized targeted therapy. Oncotarget 2016, 7, 83378-83391. [CrossRef]

(C) 2019 by the authors. Licensee MDPI, Basel, Switzerland. This article is an open access article distributed under the terms and conditions of the Creative Commons Attribution (CC BY) license (http://creativecommons.org/licenses/by/4.0/). 